ACTA IURIS STETINENSIS 2 (14)

DOI: 10.18276/ais.2016.14-04

\title{
Adam Drozdek*
}

\section{CŁO JAKO ŹRÓDŁO DOCHODÓW BUDŻETOWYCH W ŚWIETLE USTAWY O FINANSACH PUBLICZNYCH}

\begin{abstract}
Streszczenie
Problematyka niniejszego artykułu koncentruje się na analizie cła jako daniny publicznej, będącej źródłem dochodu Polski oraz organizacji międzynarodowej - Unii Europejskiej. Krajowy ustawodawca, określając katalog dochodów publicznych w art. 5 ust. 2 pkt 1 u.f.p., nie wymienia wprost ceł jako daniny publicznej, która wchodzi w zakres katalogu dochodów publicznych. O wyróżnieniu cła jako daniny publicznej spośród innych danin publicznych decyduje to, że jest jedynym świadczeniem stanowiącym nie tylko źródło dochodu budżetu Polski, ale także budżetu unijnego. Cło pełni także funkcję prohibicyjną, która realizowana jest przez utrudnienie, a nawet uniemożliwienie napływu towarów z zagranicy.
\end{abstract}

Słowa kluczowe: cło, danina publiczna, finanse publiczne

\section{Wprowadzenie}

Prawidłowe funkcjonowanie podmiotu publicznoprawnego zależy od wielu czynników politycznych i gospodarczych, wewnętrznych i zewnętrznych, materialnych oraz pozamaterialnych. Wśród nich istotną rolę odgrywa możliwość dysponowania przez związek publicznoprawny odpowiednimi środkami finansowymi (pieniężnymi), z których pokrywane są wydatki publiczne, a których

* mgr Adam Drozdek Katedra Prawa Finansowego na Wydziale Prawa i Administracji Uniwersytetu Śląskiego w Katowicach, TAX LEADER, Glumińska-Pawlic, Szymik, Oleś. Kancelaria Doradztwa Podatkowego, sp.p.; adres e-mail: adam_drozdek@poczta.onet.pl 
odpowiednia wysokość zapewnia realizację przez podmiot publicznoprawny zadań niepozostających w gestii podmiotów prywatnych. Dlatego też istotnego znaczenia wśród czynników decydujących o prawidłowym funkcjonowaniu związku publiczno-prawnego nabiera zapewnienie stałych, a zarazem wydajnych, źródeł dochodów. Od starożytności instrumentem gromadzenia dochodów publicznych było cło, obecnie jest to jedna z form danin publicznych, która zasila nie tylko budżet państwa, ale także budżet organizacji międzynarodowej, jaką jest Unia Europejska.

Przedmiotem niniejszego opracowania jest analiza relacji przepisów unijnego i krajowego prawa celnego w stosunku do regulacji ustawy o finansach publicznych ${ }^{1}$. W literaturze prawa finansowego brak jest opracowań związanych $\mathrm{z}$ przedstawieniem cła $\mathrm{w}$ świetle ustawy o finansach publicznych, niewiele uwagi poświęca temu zagadnieniu także orzecznictwo sądowo-administracyjne.

Z chwilą przystąpienia do Unii Europejskiej Polska stała się częścią unijnego obszaru celnego, przyjmując cały jego dorobek prawny. Pod pojęciem acquis communautaire rozumie się nie tylko dotychczasowe prawo unijne (pierwotne i pochodne), ale także ukształtowany sposób jego rozumienia i stosowania, politykę wspólnotową, orzecznictwo sądowe, zwyczaje oraz wartości tkwiące u podstaw funkcjonowania $\mathrm{UE}^{2}$. Istotną częścią dorobku prawnego Unii są regulacje z zakresu prawa celnego. Przepisy te należą do najbardziej zharmonizowanych regulacji na obszarze unijnym, co oznacza, że we wszystkich państwach członkowskich obowiązują jednolite zasady dotyczące wymiany międzynarodowej z zagranicą. Członkostwo Polski w strukturach unijnych spowodowało, że polskie prawo celne może być stosowane po spełnieniu dwóch podstawowych przesłanek, a mianowicie gdy

a) uregulowanie krajowego prawa celnego nie może być sprzeczne z prawem unijnym; oraz

b) prawo unijne wyraźnie dopuszcza możliwość wewnętrznego uregulowania niektórych kwestii przez poszczególne państwa członkowskie lub gdy innych zagadnień nie reguluje.

1 Ustawa z 27 sierpnia 2009 r. o finansach publicznych (tekst jedn.: Dz. U. 2013 r., poz. 885 z późn. zm.) - dalej powołana jako u.f.p.

2 S. Biernat, w: Prawo Unii Europejskiej, red. J. Barcz, Warszawa 2004, s. 204.

3 A. Kuś, Kompetencje wyłączne Unii Europejskiej w zakresie wspólnej polityki handlowej i unii celnej, Lublin 2012, s. 165. 
Przepisy unijnego prawa celnego obowiązują na terytorium RP w wyniku przekazania kompetencji organów władzy państwowej w tym zakresie na rzecz organizacji międzynarodowej, którą jest Unia Europejska ${ }^{4}$.

Badając istotę cła jako źródła dochodów budżetowych w świetle ustawy o finansach publicznych, należy rozpocząć od wyjaśnienia pojęcia „danina publiczna". Ustawa z 27 sierpnia 2009 roku o finansach publicznych posługuje się w definicją „danina publiczna”, mimo że nie ma ona definicji ustawowej ${ }^{5}$. Podejmując się analizy omawianego zagadnienia, należy stwierdzić, że pojęcie „danina” utożsamiane jest przede wszystkim z obowiązkiem przekazywania dóbr materialnych oraz usług przez podmioty podległe podmiotowi sprawującemu władzę (państwo) w celu jego utrzymania. Obowiązek ten wynika z przepisów prawa i nakładany jest jednostronnie w sposób władczy na określone podmioty, zatem z tego zbioru należy wyłączyć wszelkie świadczenia o charakterze dobrowolnym. Przymiotnik „publiczna” (drugi element składowy pojęcia) oznacza, że beneficjentem daniny jest podmiot sprawujący władzę - związek publicznoprawny, a więc państwo, samorząd terytorialny lub Unia Europejska, danina ta przekazywana jest na rachunek właściwego podmiotu publicznoprawnego. Jej publicznoprawny charakter należy wiązać z obowiązkiem ponoszenia jej na podstawie przepisów prawa publicznego. Trzecim, ostatnim elementem definicji pojęcia „daniny publicznej” jest fiskalny cel świadczenia - obowiązek ponoszenia danin publicznych wiąże się z koniecznością utrzymania administracji państwowej oraz zapewnienia jej możliwości wywiązania się ze swoich zadań. W praktyce daniny mogą być stosowane również w innym celu (obok fiskalnego), który utrudnia, a nawet uniemożliwia napływu towarów z zagranicy ${ }^{6}$.

Daniny publiczne są świadczeniami stanowiącymi dochody publiczne ${ }^{7}$, jednak ustalenie, że określone świadczenie stanowi dochód publiczny jest

4 Por. art. 90 ust. 1 Konstytucji Rzeczpospolitej Polskiej z 2 kwietnia 1997 r., (Dz. U. nr 78, poz. 483 z późn. zm.) - dalej powołana jako Konstytucja RP.

5 A. Krzywoń, Podatki i inne daniny publiczne - podstawowe pojęcia konstytucyjne, „Zeszyty Naukowe Sądownictwa Administracyjnego” 2011, nr 2, s. 47-48.

6 A. Bień-Kacała, w: Prawo i administracja, t. II, red. R. Budzinowski, Piła 2003, s. 107.

7 Nie wszystkie jednak dochody publiczne mają charakter daniny, ale tylko te, które wnosi się na zasadzie przymusu opartego na władztwie daninowym, niewynikające z umowy, orzeczenia sądu lub jednostronnego oświadczenia woli obciążonego (C. Kosikowski Ustawa daninowa w świetle standardów konstytucyjnych, w: Księga jubileuszowa profesora Ryszarda Mastalskiego. Stanowienie i stosowanie prawa podatkowego, red. W. Miemiec, Wrocław 2009, s. 248). 
niewystarczające, aby uznać je za daninę publiczną. Istotna jest bowiem cecha przymusowości danin publicznych, która wynika wprost z literalnego brzmienia art. 217 Konstytucji, mówiącego o świadczeniach „nakładanych” przez uprawniony do tego organ publicznoprawny ${ }^{8}$. Nie wszystkie dochody publiczne są daniną, można za taką uznać tylko te wnoszone na zasadzie przymusu opartego na władztwie daninowym, niewynikającym z umowy, orzeczenia sądu lub jednostronnego oświadczenia woli obciążonego".

Powyższe ustalenia pozwalają wysunąć wniosek, że daniny publiczne są zasadniczą instytucją prawa finansowego. $Z$ treści art. 217 Konstytucji RP wynika, że jedyną i zarazem podstawową daniną publiczną wymienioną z nazwy jest podatek. Ustawa zasadnicza wymienia jednak oprócz podatków również „inne daniny publiczne", ponoszone na rzecz związku publicznoprawnego ${ }^{10}$. W oparciu o wnioskowanie a contrario należy przyjąć, iż przez „inne daniny publiczne” trzeba rozumieć daniny, które nie są podatkami, ale mają cechy, które pozwalają je ujmować w tej kategorii prawnej.

W świetle powyższych przesłanek należy stwierdzić, że daniną publiczną jest przymusowe, bezzwrotne, powszechne świadczenie pieniężne o charakterze publicznoprawnym, stanowiące dochód państwa lub innego podmiotu publicznego, nakładane jednostronnie (władczo) przez organ publicznoprawny w celu zapewnienia utrzymania państwa (choć mogą mu towarzyszyć także inne cele, np. stymulacyjne, prewencyjne, prohibicyjne), które służy wypełnianiu zadań (funkcji) publicznych wynikających z konstytucji i ustaw. Daniny publiczne należą do szerszej kategorii „świadczeń publicznych”, będących stałym elementem ustroju państwa, bez którego państwo nie mogłoby funkcjonować ${ }^{11}$. Charakter prawny cła jako daniny publicznej podkreślony został nie tylko w doktrynie prawa ${ }^{12}$,

8 Wyrok TK z 19.07.2011 r., sygn. P 9/09, LEX nr 936457.

9 C Kosikowski, w: Księga..., s. 248.

10 T. Dębowska-Romanowska, Prawo daninowe - podstawowe pojęcia konstytucyjne i ustawowe, „Glosa” 1996, nr 11, s. 3; A. Krzywoń, Podatki..., s. 47; wyrok WSA w Poznaniu z 09.05.2006 r., sygn. III SA/Po 187/04, LEX nr 830558.

11 T. Dębowska-Romanowska, Pojęcie podatków i innych danin publicznych $w$ świetle konstytucji, w: Księga..., s. 120.

12 Por. K. Sawicka, Cło $w$ systemie danin publicznych, w: Księga pamiatkowa ku czci Profesora Eugeniusza Teglera, Poznań 1997, s. 131; A. Drwiłło, Cło, w: Leksykon prawa finansowego. 100 podstawowych pojęć, red. A. Drwiłło, D. Maśniak, Warszawa 2009, s. 53. 
ale także w judykaturze ${ }^{13}$. Cło jako podstawowa instytucja prawa celnego jest daniną publiczną pobieraną od podmiotów, będącymi będących uczestnikami wymiany międzynarodowej, które dostarczają środki środków finansowych służących wypełnianiu zadań (funkcji) przez związek publicznoprawnemu, jakim jest państwo i Unia Europejska. Cłu mogą towarzyszyć także inne cele, np. stymulacyjne, prewencyjne, służące wypełnianiu zadań publicznych wynikających z Konstytucji RP i ustaw ${ }^{14}$.

Podkreślić ponadto należy, że cechą charakterystyczną wyróżniającą cło na tle innych danin publicznych jest podstawa prawna jego regulacji. Stanowi ono bowiem przedmiot regulacji unijnego prawa celnego, a przepisy krajowe w tym zakresie jedynie uzupełniają prawo unijne. Tym samym cło jest jedyną daniną publiczną regulowaną na poziomie unijnym, co oznacza, że kompetencje ustawodawcze zostały przekazane na rzecz Unii Europejskiej. O wyróżnieniu cła jako daniny publicznej decyduje funkcja ochronna, realizowana przez ochronę krajowych producentów i rynku krajowego. Obecnie cła w coraz większym stopniu stają się narzędziem stymulacji i interwencji w sferę obrotu towarowego - dzięki cłom ustawodawca ma możliwość regulowania obrotu towarowego z zagranicą. Cło pobierane przez polską administrację celną zaliczane jest do konstytucyjnej kategorii danin publicznych, stanowiąc w ten sposób źródło dochodu związku publicznoprawnego (państwa, Unii Europejskiej). Istotnym jest również to, aby w prowadzonych rozważaniach instytucji cła nie utożsamiać z pojęciem należności celnych, ponieważ w skład należności wchodzą także inne elementy ${ }^{15}$, które, mimo że są pobierane w obrocie towarowym z zagranicą, to nie są daninami publicznymi ${ }^{16}$.

13 Por. wyrok TK z 06.12.2006 r., sygn. SK 25/05, LEX nr 50268, OTK ZU-A 2006, nr 11, poz. 169, LEX nr 221524; wyrok NSA w Warszawie z 02.12.2008 r., sygn. I GSK 45/08, LEX nr 969680.

14 Por. wyrok TK z 16.03.2010 r., sygn. K 24/08, LEX nr 564548, OTK-A 2010, nr 3, poz. 22, Dz. U. 2010, nr 48, poz. 285.

15 Por. art. 5 pkt 20 i art. 5 pkt 21 Rozporządzenia Parlamentu Europejskiego i Rady (UE) $\mathrm{Nr}$ 952/2013 z 9 października 2013 r. ustanawiające unijny kodeks celny (wersja przekształcona) (Dz. Urz. UE L z dn. 10.10.2013 r., nr L 269, s. 1 z późn. zm.) - dalej powołane jako UKC.

16 K. Lasiński-Sulecki, W. Morawski,Komentarz do art. 30 Traktatu o funkcjonowaniu Unii Europejskiej, LEX 2012, teza 30.9. 


\section{Środki publiczne}

Środki publiczne, należące do podstawowych kategorii finansów publicznych, stanowią dochody publiczne gromadzone w celu pokrycia wydatków publicznych oraz rozchodów publicznych ${ }^{17}$. W doktrynie prawa finansowego zwraca się uwagę na różnorodny charakter środków publicznych, przede wszystkim zauważa się, że ich katalog, zawarty w art. 5 ustawy o finansach publicznych nie zawiera klasycznej definicji, lecz ma charakter zamknięty ${ }^{18}$. Zdaniem wielu autorów katalog ten ma jednak charakter otwarty ${ }^{19}$, a argumentem przemawiającym za takim poglądem jest zastosowanie przez ustawodawcę sformułowania „z innych źródeł”. Użycie tego zwrotu oznacza, że należy zaliczyć tutaj środki publiczne, które nie zostały wymienione z nazwy w ustawie o finansach publicznych, jak np. cło.

Ustawa o finansach publicznych pojęciem środków publicznych określa różnego rodzaju przychody i dochody gromadzone w budżecie państwa i w budżetach jednostek samorządu terytorialnego oraz ujmowane w planach finansowych jednostek sektora finansów publicznych. Pod względem prawnym obejmują środki krajowe i zagraniczne, budżetowe i pozabudżetowe, przymusowe i dobrowolne, bezzwrotne i zwrotne, podatkowe i niepodatkowe, pobierane są one na podstawie odrębnych ustaw, umów międzynarodowych lub umów cywilnoprawnych (np. pożyczki i kredyty krajowe lub zagraniczne, dochody z najmu, dzierżawy, dochody ze sprzedaży likwidowanego majątku).

W art. 5 ust. 1 ustawy o finansach publicznych wymienione zostały środki publiczne przyporządkowane do pięciu kategorii. Analizując cechy charakteryzujące każdy rodzaj środków publicznych wskazać należy na trzy podstawowe typy, które gromadzone i wydatkowane są w sposób określony przez ustawę budżetową. Do środków publicznych należy zaliczyćc ${ }^{20}$ : a) dochody publiczne, które mają one charakter podstawowy, są bezzwrotne i stanowią zasilenie finansowe

17 C. Kosikowski, Finanse publiczne i prawo finansowe, Warszawa 2001, s. 125 i nast.

18 E. Ruśkowski, Komentarz do artykułu 5, w: Nowa ustawa o finansach publicznych wraz z ustawa wprowadzająca, red. E. Ruśkowski, J.M. Salachna, Gdańsk 2010, s. 42.

19 Z. Ofiarski, Komentarz do artykutu 5, w: Ustawa o finansach publicznych. Komentarz, red. M. Karlikowska, W. Miemiec, Z. Ofiarski, K. Sawicka, Warszawa 2010, s. 24.

20 B. Kucia-Guściora, Komentarz do art. 5, w:Ustawa o finansach publicznych. Komentarz, red. P. Smoleń, Warszawa 2012, s. 95. 
władz publicznych; b) przychody publiczne, mające charakter uzupełniający i najczęściej mające charakter zwrotny, a także c). środki pochodzące z budżetu UE i inne bezzwrotne środki ze źródeł zagranicznych.

W świetle powyższego należy podzielić pogląd J.M. Salachny, że środkami publicznymi są środki pieniężne, które zostały otrzymane z określonych tytułów i źródeł przez podmioty - jednostki sektora finansów publicznych lub uiszczone na rzecz budżetu publicznego ${ }^{21}$. W momencie ich pozyskania przez instytucję (lub organ władzy)wykonującą zadania publiczne stają się jej własnością, zwiększając tym samym majątek publiczny.

\section{Dochody publiczne}

Elementem składającym się na treść pojęcia środków publicznych są dochody publiczne ${ }^{22}$, na które składają się daniny publiczne ${ }^{23}$ oraz pozostałe dochody publiczne ${ }^{24}$. Katalog dochodów budżetu państwa, wskazany został w art. 60 i 111 ustawy o finansach publicznych, które są uzupełnieniem art. 5 ust. 2 ustawy o finansach publicznych, jest szeroki, ma jednak charakter otwarty, ponieważ odsyła do innych ustaw i umów międzynarodowych, w których mogą zostać określone dochody publiczne.

Funkcje dochodów publicznych należy utożsamiać przede wszystkim z celami, dla których ustanawia się tytuły dochodów publicznych lub ze skutkami, które wynikają z ich pobierania. Celem wprowadzenia danego rodzaju dochodu publicznego jest realizacja funkcji fiskalnej bądź funkcji interwencyjnej, polegającej na zachęceniu lub zniechęceniu podmiotu obciążonego świadczeniem publicznym do określonego zachowania. Podstawową zasadą wynikającą z finansów publicznych, jest to, że dochody publiczne pobiera się w celu gromadzenia środków niezbędnych do sfinansowania potrzeb publicznych. Funkcje fiskalne dochodów publicznych nie są negowane, inaczej jest jednak z funkcjami

${ }^{21}$ J.M. Salachna, Środki publiczne, ich rodzaje formy prawne oraz zasady realizacji w sektorze finansów publicznych, w: System prawa finansowego, T. II Prawo finansowe sektora finansów publicznych, red. E. Ruśkowski, Warszawa 2010, s. 85.

${ }^{22}$ Art. 5 ust. 2 u.f.p.

23 Art. 5 ust. 2 pkt 1 u.f.p.

24 Art. 5 ust. 2 pkt $2-8$ u.f.p. 
interwencyjnymi, zwłaszcza, gdy poszczególne tytuły obciążeń nie tylko nie mogą, lecz wręcz nie powinny zapewnić napływu dochodów publicznych. Cele interwencyjne dochodów publicznych są liczne i różnorodne ${ }^{25}$.

W literaturze prawa finansowego wskazuje się, że dochody publiczne należy odróżnić od dochodów prywatnych, ich odmienność wynika przede wszystkim ze sposobu tworzenia dochodów, trybu ich wymiaru, poboru i egzekucji oraz odpowiedzialności za wypełnienie zobowiązań, a także przeznaczeniem, planowaniem, wykorzystaniem (wydatkowaniem) i kontrolą gromadzenia oraz wydatkowania. Dochody publiczne są wprowadzane w sposób władczy, oparte na metodzie określonej w konstytucji danego państwa. Zasadą jest, że dochody publiczne są wprowadzane w drodze ustawy. Dochody publiczne pobierane są na cele związane z wydatkami publicznymi państwa i samorządu terytorialnego, natomiast dochody prywatne powstają najczęściej w wyniku zobowiązań cywilnoprawnych lub orzeczeń sądowych bądź decyzji administracyjnych, z których wynika obowiązek wypełnienia zobowiązania prywatnoprawnego. Dochody prywatne pozostają do swobodnej dyspozycji ich wierzycieli i jako takie mogą być przeznaczone na cele przez nich wybrane ${ }^{26}$.

W zakres dochodów publicznych, jak wcześniej zauważono, zgodnie z art. 5 ust. 2 pkt. 1 ustawy o finansach publicznych wchodzą daniny publiczne, artykuł zawiera przykładowe wyliczenie świadczeń. Daniny publiczne odnoszą się, zgodnie z treścią tej regulacji, do podatków, składek, opłat, wpłat z zysku przedsiębiorstw państwowych i jednoosobowych spółek Skarbu Państwa, a także innych świadczeń pieniężnych, których obowiązek ponoszenia na rzecz państwa, jednostek samorządu terytorialnego, państwowych funduszy celowych oraz innych jednostek sektora finansów publicznych wynika z odrębnych ustaw. Polski ustawodawca, określając katalog dochodów publicznych, wyróżnia daniny publiczne, dlatego niezbędna jest analiza wyżej wymienionych regulacji w celu ustalenia ich treści, a w efekcie umiejscowienie cła jako dochodu publicznego.

Świadczenia zaliczane do danin publicznych stanowią dochód państwa lub innego podmiotu publicznego, zaś ich istotną cechą jest przeznaczenie na wydatki lub rozchody publiczne. Zdaniem niektórych autorów np. Z. Ofiarskiego, powyższa regulacja ma charakter otwarty ${ }^{27}$, a potwierdza to użyty przez usta-

\footnotetext{
25 C. Kosikowski, Ustawa o finansach publicznych. Komentarz, Warszawa 2011, s. 40-41.

26 C. Kosikowski, Komentarz do art.5 ustawy o finansach publicznych, Lex nr 2011.

27 Z. Ofiarski, Komentarz do art.5, w: Ustawa ..., s. 25.
} 
wodawcę zwrot - „inne świadczenia pieniężne”. Oznacza to, że należą tutaj inne środki publiczne, które w regulacji nie zostały wymienione z nazwy. Powyższe powoduje zgodność się z poglądem prezentowanym w doktrynie, że art. 5 ust. 2 pkt. 1 ustawy o finansach publicznych. nie należy traktować jako definicji normatywnej pojęcia danina publiczna $\mathrm{z}$ uwagi na fakt, że stanowią one jedynie przykładowe wyliczenie świadczeń zaliczanych do tej kategorii prawnej ${ }^{28}$.

Analizując powyższą regulację warto zwrócić uwagę, że poza daninami publicznymi wymienionymi z nazwy prawodawca użył w art. 5 ust. 2 pkt. 1 zwrotu „inne świadczenia pieniężne”. Istotnym jest, że obowiązek ich ponoszenia na rzecz państwa, jednostki samorządu terytorialnego, państwowych funduszy celowych oraz innych jednostek sektora finansów publicznych ma wynikać z odrębnych ustaw. Do takich świadczeń, zdaniem niektórych autorów, zalicza się cła ${ }^{29}$, część z nich zauważa jednak, że cło należy zaliczyć zgodnie z art. 5 ust. 2 pkt. 2 do innych dochodów budżetu państwa, jednostek samorządu terytorialnego oraz innych jednostek sektora finansów publicznych należnych na podstawie odrębnych ustaw lub umów międzynarodowych ${ }^{30}$. Pogląd ten uzasadniają faktem pobierania ceł na podstawie ustaw i umów międzynarodowych.

Poglądy te na podstawie dotychczasowych rozważań należy uznać za słuszne. Analizując badaną regulację, należy zauważyć, że wśród dochodów publicznych stanowiących daniny publiczne nie wymieniono wprost ceł, jednak - jak już wykazano - należą one bez wątpienia do kategorii danin publicznych, a obowiązek ich ponoszenia na rzecz związku publicznoprawnego (państwa, Unii Europejskiej) wynika $\mathrm{z}$ odrębnych ustaw i umów międzynarodowych ${ }^{31}$. Podkreślenia wymaga fakt, że cło jest specyficznym rodzajem daniny publicznej, która pobierana jest od podmiotów dokonujących wymiany międzynarodowej i w takim rozumie-

28 K. Machalica-Drozdek, Stosunek prawny zobowiązania celno-podatkowego w obrocie towarowym z zagranica, Warszawa 2015, s. 30.

29 E. Ruśkowski, Komentarz do art. 5, w: Nowa..., s. 50; podobnie Z. Ofiarski, Komentarz do art. 5, w: Ustawa..., s. 25; C. Kosikowski, Ustawa..., s. 201.

30 R. Bucholski, Środki publiczne, nadwyżka i deficyt sektora finansów publicznych, w: Ustawa o finansach publicznych. Komentarz prawno-finansowy, red. H. Dzwonkowski, G. Gołębiowski, Warszawa 2014, s. 28.

31 Por. decyzja Rady nr 2014/335/UE, Euratom z 26 maja 2014 r. w sprawie systemu zasobów własnych Unii Europejskiej (Dz. Urz. UE. L 168 z 07.06.2014 r., s. 105) - dalej powołana jako decyzja Rady nr 2014/335/UE; Traktat z 25 marca 1957 r. o funkcjonowaniu Unii Europejskiej (wersja skonsolidowana w brzmieniu nadanym traktatem lizbońskim, Dz. Urz. UE C 83 z 30.03.2010 r., s. 47) - dalej przywoływany jako TFUE. 
niu mieści się ono w katalogu danin publicznych wymienionych w art. 5 ust. 2 pkt 1. Rozważając treść przywołanej regulacji prawnej, należy zwrócić uwagę, że katalog danin publicznych tworzą świadczenia pieniężne, stanowiące dochód państwa, jednostek samorządu terytorialnego, państwowych funduszy celowych bądź jednostek sektora finansów publicznych. Cło jest częścią dochodu nie tylko budżetu państwa, ale również Unii Europejskiej. Z chwilą przystąpienia Polski do Unii Europejskiej aż 80\% zaksięgowanych kwot wynikających z ceł odprowadzanych jest do budżetu ogólnego Unii Europejskiej ${ }^{32}$. Ustawa o finansach publicznych w art. 125 ust. 1 pkt. 2 do środków własnych Unii Europejskiej zalicza udział we wpływach z ceł, opłat rolnych i cukrowych ${ }^{33}$. W zasobach własnych Unii Europejskiej znaleźć się muszą środki na sfinansowanie prowadzonej przez nią polityki. Obecnie cła pobierane z tytułu importu towarów z państw nienależących do Unii Europejskiej stanowią dochód UE i są elementami systemu finansowego prawa unijnego ${ }^{34}$, Polska zaś jedynie poprzez swój budżet redystrybuuje pobrane na terytorium kraju cła do budżetu Unii Europejskiej.

W Polsce cła są jednymze źródeł dochodów budżetu państwa, wymienia się je jako drugi - obok podatków - podstawowy typ danin publicznych, które zapewniają wpływy ${ }^{35}$. Pomimo malejącego znaczenia fiskalnego ceł ochrona interesu fiskalnego Unii oraz państw członkowskich nadal jest jednym z podstawowych zadań regulacji prawa celnego. Pogląd ten podkreślony został w treści preambuły „Konstytucji Unii Celnej ${ }^{36 ”, ~ k t o ́ r a ~ m o ́ w i, ~ z ̇ e ~ s t o s o w a n i e ~ c e ł ~ p o w i n n o ~}$ - w miarę możliwości - służyć zapobieganiu nadużyciom lub nieprawidłowościom, mogącym przynieść uszczerbek finansowy budżetowi Unii Europejskiej.

32 Zob. art. 2 ust. 1 lit. a) oraz ust. 3 decyzji Rady nr 2014/335/UE w zw. z art. 3 i 311 TFUE; por. art. 125 u.f.p. Pogląd ten zyskał również aprobatę w doktrynie prawa finansowego: P. Sawczuk, Przesłanki stosowania wydtużonego terminu powiadomienia dtużnika o kwocie dtugu celnego w świetle praktyki orzeczniczej Europejskiego Trybunatu Sprawiedliwości, w: Prawo finansowe w warunkach członkostwa Polski w Unii Europejskiej, red. A. Pomorska, P. Smoleń, J. Stelmasiak, A. Gorgol, Lublin 2011, s. 399; C. Kosikowski, Problem suwerenności finansowej państwa członkowskiego Unii Europejskiej, w: Finanse publiczne i prawo finansowe - realia i perspektywy zmian. Ksiega Jubileuszowa dedykowana Profesorowi Eugeniuszowi Ruśkowskiemu, red. L. Etel, M. Tyniewicki, Białystok 2012, s. 99.

33 Art. 125 ust. 2 pkt 1 u.f.p.

34 A. Drwiłło, Cła i należności celne, w: System prawa finansowego, T. III, Prawo daninowe, red. L. Etel, Warszawa 2010, s. 872-873.

35 Art. 111 ust. 2 u.f.p.

36 Por. akapit 37 preambuły do UKC. 
Reasumując, należy stwierdzić, że cła są wrażliwym instrumentem prawa celnego związanym z przemieszczaniem towarów przez granicę, a zarazem najważniejszym narzędziem taryfowej polityki handlowej, którym posługuje się Unia Europejska.

Regulacja art. 5 ust. 2 pkt. 1 nie wymienia Unii Europejskiej jako beneficjenta dochodów publicznych ze źródła, jakim są daniny publiczne. W tym miejscu warto podkreślić, że regulacje unijne odgrywają znaczącą rolę wśród źródeł prawa celnego. O istotnej roli aktów prawa unijnego przesądzają przede wszystkim dwa czynniki. Po pierwsze: handel międzynarodowy pozwala na uzyskanie dostępu do zagranicznych rynków zbytu oraz surowców, przez co ma wielkie znaczenie dla większości państw, nie muszą one zawierać dwustronnych lub wielostronnych porozumień dotyczących handlu. Po drugie, co ma znaczenie w przypadku państw członkowskich Unii Europejskiej - wspólna polityka handlowa objęta jest wyłączną kompetencją Unii, a w konsekwencji państwa członkowskie nie są uprawnione do zawierania umów handlowych z państwami trzecimi, gdyż te mogłyby uniemożliwić realizację celów Unii Europejskiej.

W tym miejscu warto podkreślić, że prawo Unii Europejskiej jest szczególnego rodzaju systemem prawnym, charakteryzującym się (na tle innych) autonomiczną pozycją. Stanowi on zbiór przepisów, obejmujących akty prawne wypracowane początkowo przez Wspólnoty Europejskie, następnie przez Unię Europejską, a także częściowo przez same państwa członkowskie, które przekazały Unii część suwerennych praw i upoważniły organy unijne do samodzielnego stanowienia prawa. Wyjątkowy charakter i pozycja prawa Unii Europejskiej sprawia, że stanowi ono prawo formalnie odrębne zarówno względem publicznego prawa międzynarodowego, jak i wewnętrznych systemów prawnych państw członkowskich. W odróżnieniu od prawa publicznego międzynarodowego, którego celem jest współpraca suwerennych państw, w przypadku prawa unijnego mamy do czynienia z celem w postaci integracji państw członkowskich. Jego realizacja ma polegać na wykonywaniu powierzonych Unii kompetencji, aby osiągnąć zapisane w traktatach podstawowe założenia. Niezależność prawa Unii Europejskiej wynika również z faktu, że ma ono własny system źródeł prawa, własne procedury tworzenia, wykładnię oraz kontrolę stosowania i ochronę ${ }^{37}$. Unia Europejska jest organizacją międzynarodową, mającą osobowość prawną, swoje organy oraz personel, jednak nie ma własnej „klasycznej” administracji.

37 A. Kuś, Kompetencje..., s. 28. 
Zadania Unii Europejskiej realizowane są przez administrację poszczególnych państw członkowskich ${ }^{38}$. Autonomiczny charakter systemu prawnego Unii podkreślony został także w orzecznictwie Trybunału Sprawiedliwości Unii Europejskiej. W orzeczeniu z 13 lutego 1969 roku Trybunał podkreślił, że Unia ma swój własny system prawny, zintegrowany z systemami prawnymi państw członkowskich, który musi być stosowany przez ich sądy ${ }^{39}$. Oznacza to niezależność prawa unijnego, które nie może zostać uznane za tożsame z prawem wewnętrznym państw członkowskich, ponieważ jest tworzone przez właściwe organy prawotwórcze Unii, przy zastosowaniu odpowiednich procedur tworzenia i kontroli prawa. W tym celu Unia została zaopatrzona przez państwa członkowskie w niezbędne kompetencje i związane z tym uprawnienia. Kończąc przedstawione rozważania, należy odwołać się do poglądów C. Kosikowskiego, który stwierdził, że przepisy TFUE wskazują, iż Unia Europejska ma wyłączną kompetencję w zakresie unii celnej, w tym, m.in. kompetencje dotyczące stanowienia zasad wymiaru i poboru ceł ${ }^{40}$. Wynika to z faktu, że Unia Celna ma uprawnienie do wprowadzenia w wymianie międzynarodowej Wspólnej Taryfy Celnej oraz stanowienia na jej podstawie ceł. Z powyższego można wnioskować, że unijne prawo celne, $\mathrm{tj}$. UKC oraz rozporządzenia wykonawcze, regulowane jest prawem organizacji międzynarodowej.

Podsumowując powyższe rozważania, należy stwierdzić, że po przystąpieniu Polski do Unii Europejskiej cła stanowią w sensie podmiotowym i przedmiotowym źródło dochodów budżetu unijnego, w przeciwieństwie do pozostałych danin publicznych, które zasilają dochody budżetu państwa lub jednostek samorządu terytorialnego. Cło stanowi osobną kategorię dochodów publicznych, którą cechuje przymusowość, pobierane jest przez organy celne na podstawie Wspólnej Taryfy Celnej od podmiotów dokonujących obrotu towarowego z zagranicą, w związku z przemieszczaniem się towaru przez granicę celną państwa lub grupy państw tworzących unię celną, co podkreśla szczególny charakter tego świadczenia jako daniny publicznej. Ujęcie cła w katalogu danin

38 Ibidem, s. 165.

39 Wyrok TS z 13 lutego 1969 r., w sprawie C-14/68, Walt Wilhelm i inni v. Bundeskartellamt, zob. Orz. z 1969, s. 1.

40 Por. C. Kosikowski, w: Finanse..., s. 99-100; podobnie też K. Piech, Wprowadzanie towarów na obszar celny Unii Europejskiej, Warszawa 2012, s. 44; A. Kuś, Kompetencje, s. 69. De lege lata unia celna obejmuje nakaz stosowania jednolitej, wspólnej taryfy celnej zewnętrznej we wszystkich państwach członkowskich Unii Europejskiej (por. art. 28 TFUE). 
publicznych wynika z realizacji celów publicznych, jak również z faktu, że stanowi źródło dochodów publicznych, które jest niezbędne dla funkcjonowania związku publicznoprawnego. System zasobów własnych Unii Europejskiej zapewnia dzięki niemu odpowiednie środki finansowe na prowadzenie unijnej polityki w poszczególnych dziedzinach w sposób uporząakowany, uwzględniając potrzeby ścisłej dyscypliny budżetowej. W konsekwencji jest świadczeniem pieniężnym, którego obowiązek ponoszenia wynika z regulacji unijnego prawa celnego, a więc $\mathrm{z}$ odrębnych regulacji unijnych.

Szczegółowa analiza art. 5 ust. 2 pkt. 1 i 2 ustawy o finansach publicznych wykazała, że nie odnoszą się one wprost do instytucji ceł, które, będąc daninami publicznymi, stanowią dochód nie tylko państwa, ale przede wszystkim Unii Europejskiej. Niewątpliwym jest jednak to, że regulacja ta będzie miała zastosowanie do ceł, o czym świadczy zwrot określony w treści art. 5 ust. 2 pkt 1 u.f.p. „inne świadczenia pieniężne”. Jak ustalono wcześniej, cło jako dochód Unii Europejskiej oraz państw członkowskich regulowane jest prawem organizacji międzynarodowej, w związku z czym art. 5 ust. 2 pkt. 1 ustawy o finansach publicznych powinien zostać doprecyzowany przez dodanie ceł do katalogu danin publicznych. Ponadto regulacja ta powinna zostać poszerzona o pojęcie organizacji międzynarodowej, na rzecz której odprowadzane jest cło.

W dalszej części rozważań należy zwrócić uwagę na fakt, że środkami publicznymi są również niepodatkowe należności budżetowe. Wyliczenie zawarte w art. 60 ustawy o finansach publicznych nie ma charakteru kompleksowego, gdyż ustawodawca, używając w konstrukcji tego przepisu słowa „w szczególności”, wskazał, że powyższy katalog ma charakter otwarty i zawiera jedynie przykłady niepodatkowych należności budżetowych. W literaturze przedmiotu krytykuje się otwarty charakter tego aktu prawnego, ponieważ powoduje on brak pozytywnych rozstrzygnięć w kwestii definicji niepodatkowych należności budżetowych, może także prowadzić do niejasności interpretacyjnych dotyczących, np. kryteriów odnoszących się do doboru świadczeń wyliczonych w art. 60 u.f.p. ${ }^{41}$. Mowa jest o należnościach niemających cech podatku i opłaty, a mających charakter publicznoprawny, które rodzą stosunki o charakterze zobowiązaniowym oraz stanowią dochód budżetu państwa lub budżetu jednostki samorządu

${ }^{41}$ M. Kowalski, Niepodatkowe należności budżetowe jako danina publiczna w świetle orzecznictwa sadów administracyjnych, w: Sąowa kontrola administracji w sprawach podatkowych, red. B. Brzeziński, J.P. Tarno, Warszawa 2011, s. 227. 
terytorialnego. Niepodatkowe należności budżetowe mają szeroki zakres i obejmują wszystkie publicznoprawne świadczenia, które zostały pozbawione cech podatków i opłat, choć mogą być do nich konstrukcyjnie zbliżone ${ }^{42}$. Ich podstawą są przepisy powszechnie obowiązującego prawa, a cechą charakterystyczną podporządkowanie, w granicach wyznaczonych prawem, objętych nimi jednostek organom wyposażonym we władztwo publiczne.

Dochody niepodatkowe w systemie finansów publicznych odgrywają drugorzędną rolę. Analizując miejsce cła w systemie dochodów publicznych, należy podzielić pogląd prezentowany w literaturze przedmiotu, że cło to odrębny rodzaj źródła dochodów, wchodzący w skład systemów niepodatkowych ${ }^{43}$. Przemawia za tym fakt, że dochodami niepodatkowymi należy nazwać wszystkie daniny publiczne, które nie są podatkami. De lege lata w ustawie o finansach publicznych cło zostało wyodrębnione jako danina, która nie jest podatkiem, opłatą ${ }^{44}$, stanowi natomiast odrębne źródło dochodów budżetowych, a obowiązek nałożenia oraz uiszczenia cła wynika z regulacji unijnych i jest egzekwowany przez uprawnione do tego organy administracji celnej. Charakter cła jako niepodatkowej należności budżetowej podkreślony został w doktrynie prawa. Zdaniem m.in. K. Piecha cło należy traktować jako odrębne źródło dochodów budżetowych o charakterze niepodatkowym, do którego określenia i poboru uprawnione są organy celne ${ }^{45}$. O wyróżnieniu ceł spośród innych danin publicznych decydują łącznie trzy cechy: a)funkcje, o znacznie węższe niż funkcje podatków; b)ich nierozerwalny związek z obrotem towarowym z zagranicą oraz c) tradycja kształtowania się tej instytucji odrębnie od prawa podatkowego.

Analizując katalog źródeł dochodów budżetu państwa, należy zwrócić uwagę na zasadę ich prognostycznego charakteru. Dochody ujęte są w budżecie państwa w wielkości przewidywanej, oznacza to, że ich faktyczne wykonanie może być zarówno wyższe, jak i niższe od wielkości przyjętych w budżecie.

42 M. Zdebel, w: Prawo finansowe po transformacji ustrojowej. Międzynarodowe i europejskie prawo podatkowe. Zjazd katedr prawa finansowego i podatkowego, Łódź 5-6 czerwca 2012 r., red. I. Mirek, T. Nowak, Łódź 2014, s. 491.

${ }^{43}$ K. Sawicka, Prawo celne w zarysie, Wrocław 2003, s. 60; Z. Ofiarski, Ogólne prawo podatkowe. Zagadnienia materialno-prawne i proceduralne, Warszawa 2010, s. 19-20; A. Drozdek, Cło jako niepodatkowa należność budżetowa. Część II, „Monitor Prawa Celnego i Podatkowego” 2012, nr 1, s. 18.

44 Por. art. 111 ust. 2 u.f.p.

45 K. Piech, Wprowadzanie..., s. 26. 
Dochody budżetowe ujmuje się w załączniku do ustawy budżetowej według źródeł dochodów oraz części i działów klasyfikacji budżetowej. Wymienione wśród środków publicznych daniny publiczne, są klasycznym ciężarem nakładanym na gospodarstwa domowe i przedsiębiorstwa, a ich główną cechą jest to, że podmiot ponoszący ciężar świadczenia nie otrzymuje w zamian żadnego bezpośredniego świadczenia (korzyści). Poszczególne formy dochodów budżetowych określają i wprowadzają odrębne ustawy, zaś obowiązek ich ponoszenia na rzecz związku publicznoprawnego wynika $z$ odrębnych regulacji prawnych, nie nakłada go ustawa o finansach publicznych ani coroczna ustawa budżetowa, co podkreślone jest w regulacji art. 51 u.f.p. Stanowi ona, że umieszczenie w budżecie państwa dochodów z określonych źródeł (np. z ceł) nie obejmuje podstawy roszczeń ani zobowiązań państwa wobec osób trzecich ani roszczeń tych osób wobec państwa. Wspomniane roszczenia lub zobowiązania wynikają z ustaw szczególnych, które wprowadzają odpowiednie formy dochodów z tytułu ceł. Z punktu widzenia prowadzonych rozważań istotne jest, że cła, które zostały wymienione w art. 111 ustawy o finansach publicznych, nie wynikają z przepisów budżetowych przewidzianych $\mathrm{w}$ ustawie o finansach publicznych. Roszczenia związku publicznoprawnego o uiszczenie cła wynikają z regulacji Unijnego Kodeksu Celnego oraz ustawy Prawo celne ${ }^{46}$.

\section{Konkluzje}

Podsumowując powyższe rozważania należy stwierdzić, że od 1 maja 2004 roku cło jako jedyna wśród danin publicznych stanowi nie tylko źródło dochodów budżetu Polski, ale także jest dochodem budżetu unijnego. Pobrane przez polską administrację celną cła są w większości składkami przekazywanymi przez państwo członkowskie na rzecz organizacji międzynarodowej, jaką jest Unia Europejska. Natomiast pozostała część - 20\%, stanowi dochód budżetu państwa, którego administracja celna pobrała należności i przeznaczana jest na sfinansowanie funkcjonowania administracji celnej. Cło, tworząc system zasobów własnych, zapewnia w ten sposób odpowiednie środki na prowadzenie polityki UE w poszczególnych dziedzinach w sposób uporządkowany, przy uwzględnieniu potrzeby ścisłej dyscypliny budżetowej. W konsekwencji jest

46 Ustawa z 19 marca 2004 r. Prawo celne (tekst jedn.: Dz. U. z 2015 r., poz. 858 z późn. zm.). 
ono świadczeniem pieniężnym, którego obowiązek ponoszenia wynika z regulacji unijnego i krajowego prawa celnego, a więc z odrębnych ustaw i regulacji unijnych.

Cło jako przymusowe świadczenie pobierane jest przez organy celne na podstawie Wspólnej Taryfy Celnej od podmiotów dokonujących obrotu towarowego $\mathrm{z}$ zagranicą $\mathrm{w}$ związku z przemieszczaniem się towaru przez granicę celną państwa lub grupy państw tworzących unię celną. Będąc świadczeniem pobieranym w obrocie towarowym z zagranicą, ma charakter daniny publicznej. Ujęcie cła w katalogu danin publicznych wynika z realizacji przez to świadczenie celów publicznych, jak również z faktu, że stanowi źródło środków finansowych, które jest niezbędne dla funkcjonowania związku publicznoprawnego. Cło realizuje funkcję fiskalną, charakterystyczną dla tego rodzaju świadczeń. O wyróżnieniu cła jako daniny publicznej spośród innych danin publicznych decyduje także jego cel prohibicyjny, realizowany przez utrudnienie, a nawet uniemożliwienie, napływu towarów z zagranicy.

\section{Literatura}

Bień-Kacała A., Daniny publiczne. Próba rekonstrukcji pojęcia na tle postanowień Konstytucji RP z 1997 r. w: Prawo i administracja, T. II, red. R. Budzinowski, Piła 2003.

Biernat S., Źródła prawa Unii Europejskiej, w: Prawo Unii Europejskiej, red. J. Barcz, Warszawa 2004

Bucholski R., Środki publiczne, nadwyżka i deficyt sektora finansów publicznych, w: Ustawa o finansach publicznych. Komentarz prawno-finansowy, red. H. Dzwonkowski, G. Gołębiowski, Warszawa 2014.

Dębowska-Romanowska T., Prawo daninowe - podstawowe pojęcia konstytucyjne i ustawowe, „Glosa” 1996, nr 11.

Drozdek A., Cto jako niepodatkowa należność budżetowa, część II, „Monitor Prawa Celnego i Podatkowego" 2012, nr 1.

Drwiłło A., w: Leksykon prawa finansowego. 100 podstawowych pojęć, red. A. Drwiłło, D. Maśniak, Warszawa 2009.

Drwiłło A., Cla i należności celne, w: System prawa finansowego, T. III, Prawo daninowe, red. L. Etel, Warszawa 2010.

Kosikowski C., Finanse publiczne i prawo finansowe, Warszawa 2001.

Kosikowski C., Komentarz do art.5 ustawy o finansach publicznych, Lex 2011.

Kosikowski C., Ustawa o finansach publicznych. Komentarz, Warszawa 2011. 
Kosikowski C., Problem suwerenności finansowej państwa członkowskiego Unii Europejskiej, w: Finanse publiczne i prawo finansowe-realia i perspektywy zmian. Księga Jubileuszowa dedykowana Profesorowi Eugeniuszowi Ruśkowskiemu, red. L. Etel, M. Tyniewicki., Białystok 2012.

Kosikowski C., Ustawa daninowa w świetle standardów konstytucyjnych, w: Księga jubileuszowa profesora Ryszarda Mastalskiego. Stanowienie i stosowanie prawa podatkowego, red. W. Miemiec, Wrocław 2009.

Kowalski M., Niepodatkowe należności budżetowe jako danina publiczna $w$ świetle orzecznictwa sąów administracyjnych, w: Sadowa kontrola administracji w sprawach podatkowych, red. B. Brzeziński, J.P. Tarno, Warszawa 2011.

Krzywoń A., Podatki i inne daniny publiczne - podstawowe pojęcia konstytucyjne, „Zeszyty Naukowe Sądownictwa Administracyjnego” 2011, nr 2.

Kucia-Guściora B., Komentarz do art. 5, w: Ustawa o finansach publicznych. Komentarz, red. P. Smoleń, Warszawa 2012.

Kuś A., Kompetencje wyłączne Unii Europejskiej w zakresie wspólnej polityki handlowej i unii celnej, Lublin 2012.

Lasiński-Sulecki K., Morawski W., Komentarz do art. 30 Traktatu o funkcjonowaniu Unii Europejskiej, LEX nr 2012.

Machalica-Drozdek K., Stosunek prawny zobowiazania celno-podatkowego w obrocie towarowym z zagranica, Warszawa 2015.

Ofiarski Z., Ogólne prawo podatkowe. Zagadnienia materialno-prawne i proceduralne, Warszawa 2010.

Ofiarski Z., Komentarz do art. 5, w: Ustawa o finansach publicznych. Komentarz, red. M. Karlikowska, W. Miemiec, Z. Ofiarski, K. Sawicka, Warszawa 2010.

Piech K., Wprowadzanie towarów na obszar celny Unii Europejskiej, Warszawa 2012.

Ruśkowski E., Komentarz do art. 5, w: Nowa ustawa o finansach publicznych wraz z ustawa wprowadzająca, red. E. Ruśkowski, J.M. Salachna, Gdańsk 2010.

Salachna J.M., Środki publiczne, ich rodzaje formy prawne oraz zasady realizacji w sektorze finansów publicznych, w: System prawa finansowego, t II, Prawo finansowe sektora finansów publicznych, red. E. Ruśkowski, Warszawa 2010.

Sawczuk P., Przesłanki stosowania wydtużonego terminu powiadomienia dtużnika o kwocie dtugu celnego w świetle praktyki orzeczniczej Europejskiego Trybunatu Sprawiedliwości, w: Prawo finansowe w warunkach członkostwa Polski w Unii Europejskiej, red. A. Pomorska, P. Smoleń, J. Stelmasiak, A. Gorgol, Lublin 2011.

Sawicka K., Prawo celne w zarysie, Wrocław 2003.

Sawicka K., Cło w systemie danin publicznych, w: Księga pamiątkowa ku czci Profesora Eugeniusza Teglera, Poznań 1997.

Zdebel M., Warunki stosowania w Polsce umorzeń płatności należności budżetowych, w: Prawo finansowe po transformacji ustrojowej. Międzynarodowe i europejskie prawo podatkowe. Zjazd katedr prawa finansowego i podatkowego, Łódź 5-6 czerwca 2012 r., red. I. Mirek, T. Nowak, Łódź 2014. 


\section{Źródła prawa}

Traktat z 25 marca 1957 r. o funkcjonowaniu Unii Europejskiej (wersja skonsolidowana w brzmieniu nadanym traktatem lizbońskim, Dz. Urz. UE C 83 z dn. 30.03.2010 r., s. 47).

Rozporządzenia Parlamentu Europejskiego i Rady (UE) Nr 952/2013 z 9 października 2013 r. ustanawiające unijny kodeks celny (wersja przekształcona) (Dz. Urz. UE L z dn. 10.10.2013 r., nr L 269, s. 1 z późn. zm.).

Decyzja Rady nr 2014/335/UE, Euratom z 26 maja 2014 r. w sprawie systemu zasobów własnych Unii Europejskiej (Dz. Urz. UE. L 168 z dn. 07.06.2014 r., s. 105).

Konstytucja Rzeczpospolitej Polskiej z 2 kwietnia 1997 r., (Dz. U. nr 78, poz. 483 z późn. zm.).

Ustawa z 27 sierpnia 2009 r. o finansach publicznych (tekst jedn.: Dz. U. 2013 r., poz. 885 z późn. zm.).

Ustawa z 19 marca 2004 r. Prawo celne (tekst jedn.: Dz. U. z 2015 r., poz. 858 z późn. zm.).

\section{Orzecznictwo}

Wyrok TS z 13 lutego 1969 r., w sprawie C-14/68, Walt Wilhelm i inni v. Bundeskartellamt, zob. Orz. z 1969, s. 1.

Wyrok TK z 06.12.2006 r., sygn. SK 25/05, LEX nr 50268, OTK ZU-A 2006, nr 11, poz. 169, LEX nr 221524.

Wyrok TK z 16.03.2010 r., sygn. K 24/08, LEX nr 564548, OTK-A 2010, nr 3, poz. 22, Dz. U. 2010, nr 48, poz. 285.

Wyrok TK z 19.07.2011 r., sygn. P 9/09, LEX nr 936457.

Wyrok NSA w Warszawie z 02.12.2008 r., sygn. I GSK 45/08, LEX nr 969680.

Wyrok WSA w Poznaniu z 09.05.2006 r., sygn. III SA/Po 187/04, LEX nr 830558. 


\section{CUSTOMS DUTY AS A SOURCE OF BUDGET INCOME IN VIEW OF THE ACT ON PUBLIC FINANCES}

The topic of this article focuses on the analysis of customs duty as public levy constituting a source of income for Poland and an international organisation - the European Union. While defining a catalogue of public incomes in article 5, section 2, point 1 of the Act on Public Finances, the national legislator does not directly list customs duties as a public levy included in the public incomes catalogue. Customs duty is defined as one of public levies, since it is the only benefit constituting not only the source of income for Poland's budget, but also for the budget of the European Union. Furthermore, customs duty fulfils a prohibition function through hindering and even preventing inflow of goods from abroad.

Keywords: customs, public tribute, public finance 